\title{
ESTIMATION OF GUAIFENESIN BY RP-HPLC METHOD IN PHARMACEUTICAL SUBSTANCE AND PHARMACEUTIAL PRODUCTS
}

\author{
Manasa Merugu*, B. Sai Teja, B. Kavya Sree,
} B. Pravallika and $\mathrm{CH}$. Navya Prashanthi

Department of Pharmaceutical Analysis, Pulla Reddy Institute of Pharmacy, Domadugu (V),Gummadidala(M),Sangareddy(D), Hyderabad, Telangana, India.

\begin{abstract}
A simple, accurate and precise economic RP HPLC method was develop and validated for the estimation of Guaifenesin in Pharmaceutical substance and product. The drug was separated in CAPCELL C18 column $(250 \times 4.6 \mathrm{~mm}, 5 \mu)$ using mobile phase consisting of methanol: water $(50: 50 \% \mathrm{v} / \mathrm{v})$.The flow rate was kept constant at $1 \mathrm{~mL} / \mathrm{min}$ and eluents were detected at $209 \mathrm{~nm}$. In calibration curve experiments, linearity was found in concentration range 50-150 $\mu \mathrm{g} / \mathrm{ml}$ with regressions efficient $\mathrm{R}^{2}=0.999$. The equation obtained was $\mathrm{Y}=16468 \mathrm{x}+16614$. In accuracy studies percentage recovery was found to be $99.55 \% \mathrm{~W} / \mathrm{W}$. By performing assay percentage purity was found to be $99.99 \% \mathrm{~W} / \mathrm{W}$. Hence the method can be applicable in routine determination of Guaifenesin in pharmaceutical formulations.
\end{abstract}

Keywords: Guaifenesin, methanol, water, ICH guidelines and Analytical method validation.

\section{INTRODUCTION ${ }^{1-18}$}

Guaifenesin is a medication used to try to help cough out phlegm from the airway it is unclear if it decreases coughing, it is an expectorant it will reduce chest congest caused by common cold, infection, allergies or illness.

Guaifenesinmolecular formula is $\mathrm{C}_{10} \mathrm{H}_{14} \mathrm{O} 4$. Other name is Glycerylguaiacolate and the trade name is Barkeit. It is metabolized in kidney. IUPAC is 3-(2-methoxyphenoxy) propane-1, 2-diol. Molecular mass of Guaifenesinis $198.216 \mathrm{~g} / \mathrm{mol}$. Chemical structure of Guaifenesin shown it fig no.1.

In this research work we have developed, optimized, and validated the method using RPHPLC. Drug was assayed by validated method. The main objective of this method is to develop time saving and cost effective.

\section{MATERIALS AND METHODS} CHEMICALS AND REAGENTS

Reference standard was obtained from sigma Aldrich laboratories. The formulation used for assay is Guaifenesin is manufactured by
Barkeit and solvents used in this method were methanol and HPLC grade water.

\section{INSTRUMENTATION}

Method development and validation was carried out by RP-HPLC (Shimadzu) with PDA detector module with auto-sampler. Column used was Agilent Eclips XBD (150*4.6 * $5 \mu \mathrm{m})$, and data recorded using LC Solutions software.

\section{DILUENT}

Methanol: Water $(50: 50 \% \mathrm{v} / \mathrm{v})$

\section{PREPARATION OF STANDARD}

Weigh accurately about $100 \mathrm{mg}$ of drug and transfer it into $10 \mathrm{ml}$ volumetric flask and make up the volume up to $10 \mathrm{ml}$ using diluent and sonicated for 5 minutes. Pipette out $1 \mathrm{ml}$ of above solution into $10 \mathrm{ml}$ volumetric flask, make up the volume with diluent .obtained standard concentration is $100 \mu \mathrm{g} / \mathrm{ml}$.

\section{PREPARATION OF SAMPLE}


Take 20 tablets and triturate it. Weigh accurately equivalent to $100 \mathrm{mg}$ of tablet powder and transfer it into $10 \mathrm{ml}$ volumetric flask and make up the volume up to $10 \mathrm{ml}$ using diluent and sonicatedfor 5 minutes. Pipette out $1 \mathrm{ml}$ of above solution into $10 \mathrm{ml}$ volumetric flask, make up the volume with diluent.

\section{METHOD OPTIMIZATION}

Based on the literature of Guaifenesin and its combination, one method was developed after conducting several trails and developed method optimized.

\section{VALIDATION}

The developed method was validated foe different parameters like system suitability, Linearity, accuracy, precision, LOD, LOQ, and Robustness as per ICH guidelines.

\section{SYSTEM SUITABILITY}

By injecting it six times into the system, the chromatograms of $100 \mu \mathrm{g} / \mathrm{ml}$ were analyzed. Form chromatogram the system suitability parameters like plate count, tailing factor, capacity factor and reproducibility were determined.

\section{LINEARITY}

The solutions were prepared from stock solution at 5 concentration levels $(50,75,100$, 125 , and $150 \mu \mathrm{g} / \mathrm{ml})$. Take $10 \mu$ lvolume from each concentration solution and injected trice into the HPLC system. Chromatogram were recorded under optimized equation. A graph was plotted considering peak areas on $\mathrm{Y}$-axis and concentration on X-axis. Data treated by square linear regression analysis.Y-intercept, slope of regression constant $\left(r^{2}\right)$ were calculated.

\section{PRECISION}

Repeatability or intra-day precision: The peak areas of $100 \mu \mathrm{g} / \mathrm{ml}$ were analyzed on the same day by injecting it six times into the system. Inter-day precision also performed in different days using same method. The chromatogram was recorded and RSD was calculated., $\%$ should be more than $2 \%$.

\section{ACCURACY}

Recovery of the assay method for Guaifenesin was established by three determination of the test sample using tablets at 50\%,100\%and $150 \%$ of analyte concentration .Each solution was injected thrice $(n=3)$ into HPLC system and the average peak area was calculated from which percentage recoveries were calculated. The \% recovery should be between 98.0to102.0 as per ICH $Q_{2} R_{1}$ guidelines.

\section{LIMIT OF DETECTION AND LIMIT OF QUANTITATION}

LOD and LOQ can be calculated based on the signal to noise ratio approach, visual evaluation and standard deviation of the response and slope of the calibration curve. The slope (S) is calculated from the equation of straight line in calibration curve of the analyte. The standard deviation $(\sigma)$ is calculated based on its blank response or they-intercepts of regression line. Formulas were given below.

$$
\begin{aligned}
& L O D=(3.3 \times \text { SD }) / \text { Slope } \\
& L O Q=(10 \times \text { SD }) / \text { Slope }
\end{aligned}
$$

\section{ROBUSTNESS\& RUGGEDNESS}

Ruggedness of the method was determined by carrying out the analysis by three different analysis and the respective absorbance were noted The results was indicated by $\%$ RSD .The robustness of a method is its ability to remain unaffected under changes in parameters. Robustness was carried out by altering the flow rate $(+/-0.2 \mathrm{ml} / \mathrm{min})$, changing and mobile phase (60:50\&50:60). The standard solution comprising of Guaifenesin $(100 \mu \mathrm{g} / \mathrm{ml})$ was injected six times and \%RSD was calculated for the resultant area of the peak.

\begin{abstract}
ASSAY
Take twenty tablets of Guaifenesin and powdered it and weigh accurately equivalent about $10 \mathrm{mg}$ of label drug and take the drug into $100 \mathrm{ml}$ volumetric flask and add $30 \mathrm{mlof}$ diluent, sonicate for 5 minutes and finally make up the volume with diluent. The solution was then injected into the HPLC system .The sample was prepared in six replicates.
\end{abstract}

$\%$ Assay =

(Area of unknown X Conc of standard) $\longrightarrow \quad \times 100$

(Area of standard X Conc of unknown)

\section{RESULTS AND DISCUSSION OPTIMIZATION OF CHROMATOGRAPHIC}

Developed method was optimized for different parameters. Parameters were given in Table.1 and Fig No 2.

\section{SYSTEM SUITABILITY}

The percentage area of Relative Standard deviation (RSD) from six replicate injections was found below $2.0 \%$ (diluted standard solution, $100 \mu \mathrm{g} / \mathrm{ml}$ of Guaifenesin). Low values of RSD of replicated injections indicate that the system is precise. The results are 
presented in Table 2.

\section{LINEARITY}

The calibration curve was made by plotting the concentration on $\mathrm{X}$-axis against peak area on Y-axis. A series of Guaifenesin standard solution were prepared in the range of 50 $\mu \mathrm{g} / \mathrm{ml}-150 \mu \mathrm{g} / \mathrm{ml}$. The correlation coefficient of the curve was found to be 0.999 with a regression equation of $Y=16468 x+16614$. This is shown in figure no 3 and results were given in table no 3 .

\section{PRECISION}

Repeatability or intra-day precision: The peak areas of $100 \mathrm{ug} / \mathrm{mL}$ were analyzed on the same day by injecting it six times into the system. Inter-day precision: The peak areas of $100 \mathrm{ug} / \mathrm{ml}$ were analyzed on other day by injecting it six times into the system. \%RSD was calculated. The \%RSD was found to be $0.0063 \& 0.0029$ respectively. Results were given in table no:4.

\section{ACCURACY}

Recovery of Guaifenesin was found to be $99.40 \%$ to $99.99 \%$. The summary of $\%$ recovery of Guaifenesin was mentioned in Table 5.

\section{LIMIT OF DETECTION AND LIMIT OF QUANTITATION}

LOD and LOQ were calculated from linearity graph. The limit of Detection and limit of Quantification were found out to be $0.008 \mu \mathrm{g} / \mathrm{mL}$ and $0.025 \mu \mathrm{g} / \mathrm{mL}$ respectively.

\section{ROBUSTNESS \& RUGGEDNESS}

Robustness studies were performed by changing the flow rate $( \pm 2 \mathrm{ml} / \mathrm{min})$, column temperature $\left( \pm 5^{\circ} \mathrm{C}\right)$ and mobile phase ratio.
No significant effect was observed on system suitability parameters deliberate change such as resolution, RSD, tailing factor, or the theoretical plates of Guaifenesin. Thus, the method was found to be robust with respect to variability in applied conditions.

\section{ASSAY}

Tablet solution was injected into the HPLC system for six times and \% assay of drug was found to be99.99\%. These results were tabulated in Table No 6.

\section{CONCLUSION}

An easy, rapid and efficient Reverse-Phase HPLC method was developed for quantitative estimation of Guaifenesin in drug product and drug substance. The method was validated as per ICH Q2 (R1) guidelines. A precise, accurate, linear, robust and rugged method was found during validation. Limits of detection $0.008 \mu \mathrm{g} / \mathrm{mL}$ and limits of quantification $0.025 \mu \mathrm{g} / \mathrm{mL}$ also determined. By performing the assay of Barkeit tablet the percentage purity was found to be $99.99 \%$. Hence it was concluded that this method is useful for the determination of both pharmaceutical substance and pharmaceutical product.

\section{ACKNOWLEDGEMENTS}

We are thankful to Pulla Reddy Institute of Pharmacy (PRIP) and to the Department of Pharmaceutical Analysis Quality Assurance for providing the utmost facilities such as lab, equipment and chemicals to succeed our work.

\section{CONFLICT OF INTEREST}

The authors have no conflict of interests to disclose other than what has been acknowledged above.

Table 1: Optimized conditions of Guaifenesin

\begin{tabular}{|c|c|c|}
\hline S.NO & PARAMETER & RESULTS \\
\hline 1 & Mobile phase & Methanol :water (50:50) \\
\hline 2 & Stationary phase & CAPCELL C18 Column \\
\hline 3 & Flow rate & $1 \mathrm{ml} / \mathrm{min}$ \\
\hline 4 & Injection volume & $20 \mu$ lit \\
\hline 5 & $\lambda m a x$ & $209 \mathrm{~nm}$ \\
\hline 6 & Running time & 10 \\
\hline 7 & Retention time & 5.449 \\
\hline 8 & Area & 430559 \\
\hline 9 & Tailing factor & 1.387 \\
\hline
\end{tabular}

Table 2: System Suitability 
Results of Guaifenesin

\begin{tabular}{|c|c|c|}
\hline S.no & Area & Tailing Factor \\
\hline 1 & 661794 & 5.449 \\
\hline 2 & 661763 & 5.449 \\
\hline 3 & 661797 & 5.449 \\
\hline 4 & 661752 & 5.449 \\
\hline 5 & 661689 & 5.449 \\
\hline 6 & 661795 & 5.449 \\
\hline Avg & \multicolumn{3}{|c|}{$\mathbf{6 6 1 7 6 5}$} \\
\hline SD & \multicolumn{2}{|c|}{$\mathbf{0 . 0 0 6 3}$} \\
\hline \%RSD & \multicolumn{2}{|c}{} \\
\hline
\end{tabular}

Table 3: Linearity Results of Guaifenesin

\begin{tabular}{|c|c|c|}
\hline Conc & Area & Average \\
\hline \multirow{3}{*}{$50 \mu \mathrm{g} / \mathrm{ml}$} & 328248 & \multirow{2}{*}{328881.3} \\
\cline { 2 - 2 } & 329148 & \\
\cline { 2 - 2 } & 329248 & \\
\hline \multirow{3}{*}{$75 \mu \mathrm{g} / \mathrm{ml}$} & 498247 & \multirow{3}{*}{495561.3} \\
\cline { 2 - 2 } & 489195 & \multirow{3}{*}{661729.3} \\
\cline { 2 - 2 } & 499242 & \multirow{3}{*}{829379.6} \\
\hline \multirow{3}{*}{$100 \mu \mathrm{g} / \mathrm{ml}$} & 661725 & \\
\cline { 2 - 2 } & 661768 & \multirow{2}{*}{985380.6} \\
\cline { 2 - 2 } $125 \mu \mathrm{g} / \mathrm{ml}$ & 661695 & \\
\cline { 2 - 2 } & 829373 & 829292 \\
\cline { 2 - 2 } & 829474 & \\
\hline \multirow{3}{*}{$150 \mu \mathrm{g} / \mathrm{ml}$} & 985374 & \\
\cline { 2 - 2 } & 985294 & \\
\cline { 2 - 2 } & 985474 & \\
\hline
\end{tabular}

Table 4: Intra-day\& Inter day Precision results of Guaifenesin

\begin{tabular}{|c|c|c|c|c|}
\hline \multirow{2}{*}{ S.No } & \multicolumn{2}{|c|}{ Intra-day Precision } & \multicolumn{2}{c|}{ Inter-day Precision } \\
\cline { 2 - 5 } & RT (min) & Area & RT (min) & Area \\
\hline 1 & 4.034 & 661794 & 4.034 & 661814 \\
\hline 2 & 4.034 & 661763 & 4.034 & 661793 \\
\hline 3 & 4.034 & 661797 & 4.034 & 661827 \\
\hline 4 & 4.034 & 661752 & 4.034 & 661792 \\
\hline 5 & 4.034 & 661689 & 4.034 & 661819 \\
\hline 6 & 4.034 & 661795 & 4.034 & 661775 \\
\hline \multicolumn{2}{|c|}{ Avg } & 661765 & 661803.3 \\
\hline \multicolumn{2}{|c|}{ SD } & 41.74 & \multicolumn{2}{c|}{19.78} \\
\hline \multicolumn{2}{|c|}{$\%$ SD } & 0.0063 & \multicolumn{2}{c|}{0.0029} \\
\hline
\end{tabular}

Table 5: Accuracy results of Guaifenesin

\begin{tabular}{|c|c|c|c|c|c|c|}
\hline Conc Level & Area & STD Area & Conc added & Conc Recovery & \% Recovery & Avg \\
\hline \multirow{3}{*}{$50 \%$} & 328248 & 661765 & 50 & 49.60 & 99.20 \\
\cline { 2 - 6 } & 329148 & 661765 & 50 & 49.74 & 99.48 \\
\cline { 2 - 7 } & 329248 & 661765 & 50 & 49.75 & 99.51 \\
\hline \multirow{3}{*}{$100 \%$} & 661725 & 661765 & 100 & 99.99 & 99.99 \\
\cline { 2 - 7 } & 661768 & 661765 & 100 & 100.00 & 99.00 \\
\cline { 2 - 7 } & 661695 & 661765 & 100 & 99.99 & 99.27 \\
\hline \multirow{3}{*}{$150 \%$} & 985374 & 661765 & 150 & 148.90 & 99.26 \\
\cline { 2 - 6 } & 985294 & 661765 & 150 & 148.89 & 99.28 \\
\cline { 2 - 6 } & 985474 & 661765 & 150 & 148.92 & \\
\hline
\end{tabular}

Table 6: Assay Results of Guaifenesin

\begin{tabular}{|c|c|c|}
\hline S.No & Sample Area & Standard Area \\
\hline 1 & 661684 & 661794 \\
\hline 2 & 661813 & 661763 \\
\hline 3 & 661792 & 661797 \\
\hline 4 & 661622 & 661752 \\
\hline 5 & 661789 & 661689 \\
\hline 6 & 661835 & 661795 \\
\hline Avg & $\mathbf{6 6 1 7 5 5 . 8 3 3}$ & $\mathbf{6 6 1 7 6 5}$ \\
\hline \% Assay & \multicolumn{2}{|c|}{$\mathbf{9 9 . 9 9}$} \\
\hline
\end{tabular}


<smiles>COc1ccccc1OCC(O)CO</smiles>

Fig. 1: Structure of Guaifenesin

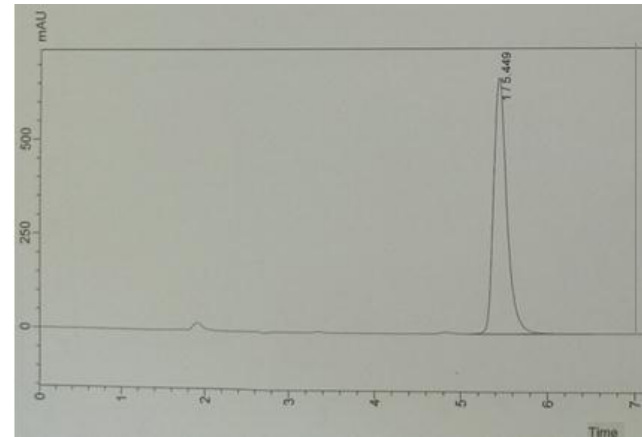

Fig. 2: Optimized Chromatogram of Guaifenesin

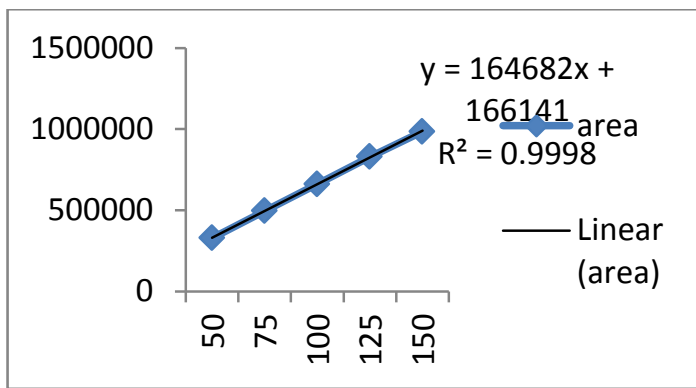

Fig. 3: Linearity Graph of Guaifenesin

\section{REFERENCES}

1. Available at Pharamatutor. org/pharma-analysis.

2. Hostettmann $\mathrm{K}$ and Marston A. Preparative Chromatography Techniques Applications in Natural Product Isolation.1998.

3. Available at satyapsingh. files.wordpress.com/2012/09/chromat ography-and-distillation.pdf.

4. Available at https://en. wikipedia.org/wiki/Chromatography\# Affinity chromatography.

5. Pharmaceutical analysis instrumental methods vol-2 by A.V. Kasture, wadodkar, mahadik, H.N. More. 4-11.

6. Available at https://en. wikipedia.org/wiki/High-performance liquid chromatography.
7. Mukthi Thammana. A Review on High Performance Liquid Chromatography (HPLC).Journal of Pharmaceutical analysis. 2016;5(2):22-28.

8. Available at.http://chromatographyscience.blogs pot.in/2012/10/parts- of- highperformance liquid. html\#. WqfhABIS3IU.

9. Available at http://labtraining.com/landing/free-hplc-trainingprogramme-8/

10. Validation of analytical procedures text and methodology. Q2 (R1) 1994;4.

11. Available at https:// www. sciencedirect.com/science/article/pii/S 2095177913001007.

12. Available at https://en. wikipedia. org/wiki/File:Guaifenesin.svg. 
13. Available

at h ttps://www.google.com/url?sa=i\& source =imgres\&cd $=\& c a d=$ rja\&uact $=8 \& \mathrm{ved}=2 \mathrm{ahUKEwjm6}$ _qfsLDoAhUex DgGHe1_BhUQjB16BAgBEAM\&URL= https\%3A\%2F\%2Fen.wikipedia.org\%2 Fwiki\%2FGuaifenesin\&psig=AOvVaw 1G_BQDS80HcKQXiWYiJiF1\&ust=15 85045360346613.

14. Sunil Pingili Reddy, K Sudhakar Babu, Navneen Kumar and Sasi Sekhar. Development and validation of stability indicating the RP-HPLC method for the estimation of related compounds of Guaifenesin in pharmaceutical dosage forms.Pharmaceutical methods. 2011;2(4):229-234.

15. Raja Abhilash Punagoti. Development and validation of new RP-HPLC method for the quantitative estimation of Guaifenesin in tablet Dosage form. Acta Scientific Pharmaceutical Sciences. 2017;1(1):25-29.

16. Available at (http://www.derpharmachemica.com/a rchive.html)

17. Levon A Melikyan, Rosa S Grigoryan and Tigran K Davtyan. Development and validation of RP-HPLC method for stimultaneous determination of Guaifenesin. Global Journals Inc. 2014;14(2).

18. Harshal Patil, Sandeep Sonawane and Paraag Gide. Determination on Guaifenesin from spiked human plasma using RP-HPLC with UV detection. Journal of Analytical Chemistry volume. 2014;69:390-394. 